Issue 2 (Oktober, 2017)

\title{
Relevansi Kompensasi, Pengembangan Karir dan Lingkungan Kerja Pada Kepuasan Kerja
}

\author{
Nurhidayat 1), Herman Sjahruddin2), Orfyanni S. Themba 3) \\ nurhidayat2294@gmail.com
}
1) Mahasiswa Program Studi Manajemen pada Sekolah Tinggi Ilmu Ekonomi Bongaya Makassar
2,3) Dosen Program Studi Manajemen pada Sekolah Tinggi Ilmu Ekonomi Bongaya Makassar

\begin{abstract}
ABSTRAK
Penelitian ini bertujuan untuk menguji dan menganalisis faktor-faktor yang mempengaruhi kualitas kehidupan kerja terhadap kepuasan kerja pegawai pada kantor Kesatuan Bangsa dan Politik Kota Makassar. Pengumpulan data dilakukan dengan menyebarkan kuesioner pada 63 pegawai sebagai responden. Penarikan sampel dilakukan dengan teknik total sampling. Analisis data dilakukan dengan menggunakan analisis diskriminan. Hasil analisis memberikan bukti bahwa kompensasi, pengembangan karir dan lingkungan kerja dari dimensi kualitas kehidupan kerja belum mampu sepenuhnya meningkatkan kepuasan kerja pegawai, sehingga dari hasil penelitian tersebut membuktikan bahwa kompensi dan lingkungan kerja berpengaruh positif dan tidak signifikan. Bukti lainnya, hasil penelitian ini membuktikan bahwa pengembangan karir berpengaruh dominan terhadap kepuasan kerja pegawai

Kata kunci : Kompensasi, Pengembangan Karir, Lingkungan Kerja, Kepuasan Kerja
\end{abstract}

\section{ABSTRACT}

This study is to determine and analyze the factors influencing work-life quality on employees' job satisfaction at the office of nationality and politics board of Makassar city. Collecting the data was conducted by distributing 63 questionnaires to respondents. This study was using saturation sample or total sample technique. The data was analyzed by using discriminant analysis. The results of analysis proved that the compensation, career development and work environment of work-life quality were not fully improved employees' job satisfaction, in order that the results of the study showed that the compensation, work environment had a positive and insignificant influence. Moreover, the result of the study proved that the career development had a dominant influence on the employees' job satisfaction

Keywords: compensation, career development, work environment, job satisfaction

\section{Latar Belakang}

Aparatur Sipil Negara (disingkat ASN) adalah profesi bagi Pegawai Negeri Sipil dan pegawai pemerintah dengan perjanjian kerja yang bekerja pada instansi pemerintah. Pegawai ASN terdiri dari Pegawai Negeri Sipil dan pegawai pemerintah dengan perjanjian kerja yang diangkat oleh pejabat pembina kepegawaian dan 


\section{JURNAL ORGANISASI DAN MANAJEMEN}

Issue 2 (Oktober, 2017)

diserahi tugas dalam suatu jabatan pemerintahan atau diserahi tugas negara lainnya dan digaji berdasarkan peraturan perundang-undangan. Kantor Pemerintahan Kota Makassar merupakan instansi pemerintahan yang beralamat di Jalan Jend. Ahmad Yani No.2, Kota Makassar, Sulawesi Selatan. Visi Pemerintah Kota Makassar yaitu Merekonstruksi nasib rakyat menjadi masyarakat sejahtera standar dunia, Merestorasi tata ruang kota menjadi kota nyaman kelas dunIa serta Mereformasi tata pemerintahan menjadi pelayanan publik kelas bebas korupsi.

Satuan Kerja Perangkat Daerah dalam hal ini SKPD Kesatuan Bangsa dan Politik Kota Makassar merupakan Satuan Kerja Pemerintahan yang mempunyai tugas melaksanakan penyusunan dan pelaksanaan kebijakan daerah dibidang kesatuan bangsa dan politik. (Pasal 47 Ayat 1 Peraturan daerah Nomor 12 Tahun 2010 Tentang Pembentukan, Organisasi Dan Tata Kerja Perangkat Daerah Kota Metro). Berdasarkan regulasi tersebut dapat disimpulkan bahwa SKPD Kesatuan Bangsa dan Politik mempunyai tugas memberi dukungan atas penyelenggaraan Pemerintahan daerah dibidang kesatuan bangsa dan politik. Untuk pencapaian visi tersebut pegawai atau yang disebut dengan Aparatur Sipil Negara (ASN) dituntut untuk mampu meningkatkan kinerjanya didalam pelayanan masyarakat, oleh karena itu pemerintah Kota Makassar dituntut untuk meningkatkan kepuasan kerja dari para pegawai (ASN) sebagai unsur terpenting dalam pencapaian visi Pemerintah Kota Makassar.

\section{Tinjauan Pustaka}

\section{Kepuasan kerja}

Kepuasan kerja merupakan istilah evaluative yang menggambarkan perasaan/sikap suka atau tidak suka. Kepuasan kerja (job satisfaction) merupakan keadaan emosional individu dalam bekerja di mana terjadi ataupun tidak terjadi titik temu antara nilai balas jasa yang memang diinginkan oleh individu tersebut (Simamora, 2006; dalam Supatmi, S. dkk., 2013). Faktor dominan yang mempengaruhi tinggi ataupun rendahnya kepuasan kerja yang dirasakan individu dalam bekerja adalah faktor kualitas kehidupan kerja, yang dijabarkan (Robbins, 1996; dalam Nugroho. dkk., 2012) melalui :

a. Pekerjaan yang menantang merupakan perwujudan dari Lingkungan Kerja. Pegawai cenderung menyukai pekerjaan yang memberi mereka kesempatan untuk menggunakan keahlian dan ketrampilan, menawarkan berbagai macam tugas, serta kebebasan dan umpan balik atas pekerjaan mereka. Pegawai yang mengendalikan pekerjaannya sendiri akan lebih puas bekerja daripada pegawai yang dikendalikan oleh mesin.

b. Penghargaan yang sepadan merupakan perwujudan dari Kompensasi.

c. Salah satu hal penting bagi pegawai adalah persepsi keadilan. Pegawai mencari kebijakan dan praktik promosi yang adil. Promosi menawarkan kesempatan untuk pertumbuhan pribadi, tanggung jawab yang lebih besar, dan peningkatan status sosial.

d. Kondisi kerja yang mendukung merupakan perwujudan dari Lingkungan Kerja. Pegawai memperhatikan ling-kungan kerjanya demi kenyamanan pribadi dan dukungan untuk bekerja dengan baik.

e. Rekan kerja yang mendukung merupakan perwujudan dari lingkungan kerja. Selain bekerja untuk mendapatkan uang dan prestasi, pegawai juga berusaha memenuhi kebutuhan akan interaksi sosial. Kepuasan kerja akan meningkat apabila didukung oleh rekan kerja yang ramah, perilaku atasan 


\section{JURNAL ORGANISASI DAN MANAJEMEN}

Issue 2 (Oktober, 2017)

yang penuh perhatian, memberi pujian atas kinerja yang baik, mendengarkan pendapat pegawai, dan menunjukkan ketertarikan pribadi terhadap pegawainya.

f. Kesesuaian antara pekerjaan dan kepribadian individu merupakan perwujudan dari Pengembangan karir. Pekerjaan yang sesuai dengan kepribadian individu akan berpendapat bakat dan kemampuan mereka sesuai dengan tuntutan pekerjaan. Pegawai yang bisa mengekspresikan diri di dalam pekerjaannya akan lebih sukses dalam bekerja dan berhasil mencapai kepuasan kerja.

Penelitian ini menggunakan pengukuran kualitas kehidupan kerja yang diadopsi dari Arifin (2012), bahwa faktor-faktor yang mempengaruhi kualitas kehidupan dijelaskan melalui dimensi kompensasi, dan pengembangan kerja serta lingkungan kerja. Berdasarkan teorinya kepuasan kerja yang dikemukakan oleh (Mc.Gregor dalam Kardila, dkk., 2016) menjelaskan bahwa tinggi ataupun rendahnya kepuasan kerja di pengaruhi oleh kompensasi, pengembangan karir dan lingkungan kerja. Teori tersebut dijadikan landasan yang mendasari terjadinya hubungan antar variabel dalam penelitian ini yaitu pengaruh faktor-faktor kualitas kehidupan kerja terhadap kepuasan yang dicerminkan melalui faktor kompensasi, lingkungan kerja serta pengembangan karir.

\section{Kompensasi}

Kompensasi merupakan salah satu faktor kualitas kehidupan kerja yang mempengaruhi kepuasan kerja pegawai. Kompensasi bagi pegawai merupakan ukuran kesuksesan dari pekerjaan mereka, kompensasi sebagai layanan moneter dan non moneter yang diterima karyawan (Davis K dan Newstrom. 1995 dalam Nugroho, dkk.,2012).

Kompensasi dapat diukur melalui dua indikator yaitu kompensasi finansial dan non finansial (Veithzal 2010:742 dalam Anas, K. 2013). Yang terdiri dari kompensasi finansial langsung dan tidak langsung dengan pernyataan seperti upah, gaji atau komisi, asuransi kesehatan dan kecelakaan, pemberian jaminan nasional dan imbalan pretasi. Sedangkan kompensasi non finansial dapat diukur dengan pernyataan seperti pekerjaan dan lingkungan. Peneltian terdahulu menjelaskan bahwa terdapat pengaruh yang signifikan antara kompensasi terhadap kepuasan kerja (Fathonah dan Utami, 2012), Hasil tersebut berbeda dengan temuan Harvey, $\mathrm{H}$ (2010) bahwa kompensasi tidak signifikan pengaruhnya terhadap kepuasan kerja.

\section{Lingkungan kerja}

Selain kompensasi, faktor lain yang mempengaruhi kepuasan pegawai dalam bekerja yaitu lingkungan kerja. Lingkungan kerja dalam penelitian ini di ukur dengan indikator lingkungan kerja fisik dan lingkungan kerja non fisik (Sedarmayanti. 2001:21; dalam Anas, K. 2013). Lingkungan kerja adalah keseluruhan sarana dan prasarana yang ada di sekitar karyawan yang sedang melakukan pekerjaan itu sendiri. Lingkungan kerja ini meliputi: tempat kerja, fasilitas dan alat bantu pekerjaan, kebersihan, pencahayaan, ketenangan termasuk juga hubungan antara orang-orang yang ada di tempat tersebut (Veitzhal 2004:165; dalam Anas, K. 2013).

Temuan peneliti terdahulu menunjukkan bahwa lingkungan kerja berpengaruh positif dan signifikan terhadap kepuasan (Dhermawan 2012). Hasil 


\section{JURNAL ORGANISASI DAN MANAJEMEN}

Issue 2 (Oktober, 2017)

penelitian tersebut berbeda dengan temuan Paramita, W. dkk., (2013) bahwa lingkungan kerja tidak signifikan pengaruhnya terhadap kepuasan kerja.

\section{g. Pengembangan karir}

Pengembangan karir merupakan faktor yang mempengaruhi kepuasan pegawai selain faktor kompensasi dan lingkungan kerja. pengembangan karier adalah proses peningkatan kemampuan kerja individu yang dicapai dalam rangka mencapai karier yang diinginkan (V. Rivai dan E. J. Sagala. 2009; dalam Nugroho 2012). Pengembangan karier dapat diukur dengan indikator Pengembangan karier organisasional dan Pengembangan karier individual (Bernardin. 2003 dalam Nugroho 2012). Hasil temuan peneliti terdahulu memberikan bukti bahwa pengembangan karier berpengaruh signifikan terhadap kepuasan kerja (Nugroho, 2012). Hasil tersebut berbeda dengan temuan Fathonah (2010) bahwa pengembangan karir tidak signifikan pengaruhnya terhadap kepuasan kerja.

Berdasarkan perbedaan hasil penelitian terdahulu tersebut, maka peneliti tertarik menguji kembali pengaruh antara variable tersebut. Fakta lapangan berdasarkan pengamatan yang dilakukan pada saat pra penelitian ditemukan adanya ketidak puasan pegawai ASN terhadap pemberian kompensasi yang mereka peroleh (insentif). Jumlah insentif yang diberikan berdasarkan nilainya tidak sama atau berbeda antara satu ASN dengan ASN lainnya, Terdapat ASN yang memberikan kontribusi yang lebih besar dalam menyelesaikan pekerjaan namun insentif yang diberikan kepadanya rendah, disisi lain terdapat ASN yang kontrubusi rendah namun insentif yang diberikannya tinggi.

\section{Metode Penelitian}

Berdasarkan jenisnya, penelitian ini termasuk dalam penelitian penjelasan (explanatory research) dalam penelitian ini peneliti menggunakan penelitian explanatory (penjelasan) bertujuan untuk menguji hubungan antara variabel atau bagaimana suatu variabel mempengaruhi variabel lainnya. Penelitian ini juga termasuk pendekatan penelitian kuantitatif, disebut kuantitatif karena banyak menggunakan angka, mulai dari pengumpulan data, penafsiran terhadap data serta dari penampilan dan hasilnya, demikian juga dengan pemahaman akan kesimpulan penelitian. (Arikunto, 2002 : 9, dalam Sinolla, 2011)

Populasi merupakan keseluruhan dari unit analisa yang ciri-cirinya akan diduga. Populasi adalah sejumlah individu yang paling sedikit mempunyai sifat atau kepentingan yang sama ( Indriantoro dan Supomo, 2002; dalam Adi Tama, 2010). Populasi dalam penelitian ini adalah Pegawai Negeri Sipil Pada Kesatuan Bangsa dan Politik (KESBANGPOL) Kantor Balaikota Makassar sebanyak 63 orang sehingga penarikan sampel dalam penilitian ini menggunakan sampel jenuh. Metode pengumpulan data dalam penelitian ini menggunakan observasi, kuesioner, itemitem pernyataan yang diajukan dalam skala nominal. Penelitian ini menggunakan teknik analisis uji instrument, uji analisis statistic deskriptif dan uji analisis regresi diskriminan yang dilakukan dengan menggunakan program SPSS 21.

\section{Hasil Penelitian}

\section{Karakteristik responden}

Profil responden pada penelitian ini menunjukan bahwa 55.65\% responden adalah pria dan $44.4 \%$ adalah perempuan. Rentang usia responden dalam penelitian ini berkisar antara 20 tahun hingga 51 tahun, diamana mayoritas responden atau 


\section{JURNAL ORGANISASI DAN MANAJEMEN}

Issue 2 (Oktober, 2017)

47.6\% berusia antara 20-30 tahun, $31.7 \%$ berusia antara $41-50$ tahun, $17.5 \%$ berusia antara diatas 51 tahun dan 3.2\% berusia antara 31-40 tahun. Berdasarkan masa kerja pada penelitian ini, mayoritas responden atau $46.0 \%$ masa kerja lebih dari 15 tahun, 44.4\% masa kerja kurang dari 1 tahun, 6.3\% masa kerja 1-5 tahun dan 3.2\% masa kerja 6-10 tahun.

Berdasarkan pendidikan pada penelitian ini, mayoritas responden atau 47.6\% pendidikan sarjana, $34,9 \%$ pendidikan diploma dan $17.5 \%$ pendidikan sma/sederajat. Berdasarkan pekerjaan lainnya pada penelitian ini, mayoritas responden atau $73 \%$ yang tidak memiliki pekerjaan lainnya dan $27 \%$ yang mempunyai pekerjaan lainnya. Berdasarkan status nikah pada penelitian ini, mayoritas responden atau $52.4 \%$ yang belum nikah dan $47.6 \%$ yang sudah nikah.

\section{Uji Instrumen}

Uji validitas menunjukkan sejauh mana ketepatan, kesesuaian, atau kecocokan suatu alat untuk mengukur apa yang akan diukur. Suatu indikator dikatakan valid jika nilai person correlation $(\mathrm{r}=>0.30)$ dan tingkat signifikansinya $(\alpha$ $=<0.05$ ) (Murti dan Salamah, 2006:65, dalam Raditya, 2016). Uji reliabilitas data dilakukan dengan menghitung crobanch's alpha dari masing-masing instrumen dalam suatu konstruk. Instrumen dikatakan handal (reliabel) apabila memiliki crobanch's alpha = >0,60 (Arikunto, 1998:164, dalam Sahlan, dkk., 2015).

Tabel 1. Uji Instrumen Penelitian

\begin{tabular}{|c|c|c|c|}
\hline variabel & pearson correlation & sig. (2-tailed) & crobanch's alpha $>0,60$ \\
\hline \multirow{2}{*}{ Kompensasi } & $0.893^{* *}$ & 0.000 & \multirow{2}{*}{0.708} \\
\hline & $0.867^{* *}$ & 0.000 & \\
\hline \multirow{2}{*}{ Pengembangan Karir } & $0.876^{* *}$ & 0.000 & \multirow{2}{*}{0.611} \\
\hline & $0.822^{* *}$ & 0.000 & \\
\hline \multirow{5}{*}{ Lingkungan Kerja } & $0.727^{* *}$ & 0.000 & \multirow{5}{*}{0.652} \\
\hline & $0.783^{* *}$ & 0.000 & \\
\hline & $0.792^{* *}$ & 0.000 & \\
\hline & $0.431^{* *}$ & 0.000 & \\
\hline & $0.469^{* *}$ & 0.000 & \\
\hline
\end{tabular}

Hasil Uji Validitas instrumen berada diatas angka kritik tabel dan memiliki nilai signifikansi dibawah 0,05 . Hal tersebut berarti bahwa seluruh butir pernyataan pada variabel kompensasi, Pengembangan karir dan Lingkungan kerja mempunyai criteria valid. Nilai cronbach's alpha atas variable kompensasi sebesar 0.708, pengembangan karir sebesar 0.611dan lingkungan kerja sebesar 0.652. Dengan demikian, dapat disimpulkan bahwa pernyataan dalam kuesioner ini reliabel karena mempunyai nilai cronbach's alpha lebih besar dari 0,60.

Author : Nurhidayat et al. (Oktober, 2017). 78 - 89

Halaman 82 https://dx.doi.org/10.17605/OSF.IO/KY6NQ 


\section{JURNAL ORGANISASI DAN MANAJEMEN}

Issue 2 (Oktober, 2017)

Pengujian normalitas dilakukan terhadap masing-masing variable secara individual maupun melalui multivariate dari nilai residual regresi. Pengujian dilakukan dengan menggunakan uji kolmogrov smirnov.

Tabel 2. Uji Normalitas Data

One-Sample Kolmogorov-Smirnov Test

\begin{tabular}{|c|c|c|}
\hline & & $\begin{array}{l}\text { Unstandardized Predicted } \\
\text { Value }\end{array}$ \\
\hline \multicolumn{2}{|l|}{ N } & 63 \\
\hline \multirow[t]{2}{*}{ Normal Parametersa,b } & Mean & 1.2857143 \\
\hline & $\begin{array}{l}\text { Std. } \\
\text { Deviation }\end{array}$ & .16770515 \\
\hline \multirow{3}{*}{$\begin{array}{l}\text { Most Extreme } \\
\text { Differences }\end{array}$} & Absolute & .120. \\
\hline & Positive & .120 \\
\hline & Negative & -.065 \\
\hline \multicolumn{2}{|l|}{ Kolmogorov-Smirnov Z } & .953 \\
\hline \multicolumn{2}{|l|}{ Asymp. Sig. (2-tailed) } & .323 \\
\hline
\end{tabular}

Berdasarkan tabel diatas mengacuh pada nilai Asymp. Sig. (2-tailed), maka harus dibandingkan dengan tingkat alpha sebesar $5 \%$ atau 0,05 . Criteria yang digunakan yaitu $\mathrm{H}_{0}$ diterima apabila nilai Asymp. Sig. (2-tailed) 0,323 > 0,05 dari tingkat alpha yang ditetapkan yaitu 5\%, sehingga dapat disimpulkan bahwa data yang di analisis berdistribusi secara normal.

\section{Analisis Regresi Diskriminan}

Analisis diskriminan, yaitu metode statistik untuk mengelompokkan atau mengklasifikasi sejumlah objek ke dalam beberapa kelompok pada variabel kualitas kehidupan kerja ( grup yang tidak puas dalam bekerja = pegawai yang tidak merasa puas dan grup yang merasa puas dalam bekerja = pegawai yang merasa puas ), sehingga setiap objek menjadi anggota dari satu kelompok.

\section{a) Uji Kesamaan Matrix Ragam-Peragam}

Untuk menguji kesamaan matrix ragam peragam antar grup yang tidak merasa puas dalam bekerja yaitu pegawai yang tidak merasa puas dengan grup yang merasa puas dalam bekerja yaitu pegawai yang merasa puas, maka ditunjukkan pada tabel berikut. 
Issue 2 (Oktober, 2017)

Tabel 3. Log Determinant

\begin{tabular}{|l|r|r|}
\hline & & \\
Kepuasan & Rank & Log Determinant \\
\hline tidak puas & 3 & -5.452 \\
Puas & 3 & -4.873 \\
Pooled within-groups & 3 & -5.224 \\
\hline
\end{tabular}

The ranks and natural logarithms of determinants printed are those of the group covariance matrices.

Grup yang merasa tidak puas dalam bekerja dan grup yang merasa puas dalam bekerja memiliki matrix ragam-peragam yang sama dilihat nilai signifikan $0.714>0.05$ (alpha). Asumsi semua grup memiliki matrix ragam-peragam yang sama terpenuhi. Selain itu, kesimpulan dapat diambil dengan nilai log determinan dari tiap-tiap grup pada tabel log determinans. Nilai log determinan pada kepuasan kerja pegawai yang tidak merasa puas $=-5.452$ dan kepuasan kerja pegawai yang merasa puas $=-4.873$. Hasil keduanya relatif sama, hal tersebut mengindikasikan ragam-peragam untuk tiap grup sama. Dengan melihat nilai signifikansi yang lebih kecil dari alpha 0.05 , sehingga dapat dikatakan bahwa terdapat perbedaan rata-rata antara tidak puas dalam bekerja dan merasa puas dalam bekerja dengan asumsi perbedaan rata-rata antar grup terpenuhi.

\section{b) Hasil Uji Box's M}

Salah satu asumsi yang harus ada dalam analisis diskriminan adalah homogenitas varians. Nilai homogenitas dapat dilihat dari nilai Statistic Box's M. Hipotesis

$\mathrm{H}_{0}$ : Varians antara dua kelompok data identik / homogen

$\mathrm{H}_{\mathrm{a}}$ : Varians antara dua kelompok data tidak identik / heterogen

Tabel 4. Box's M

\begin{tabular}{|c|c|c|}
\hline $\begin{array}{l}\text { Box's M } \\
\text { F }\end{array}$ & $\begin{array}{l}\text { Approx. } \\
\text { df1 } \\
\text { df2 } \\
\text { Sig. }\end{array}$ & $\begin{array}{r}4.014 \\
0.621 \\
6 \\
6680.91 \\
0.714\end{array}$ \\
\hline
\end{tabular}

Tests null hypothesis of equal population covariance matrices.

Tolak Hipotesis nol apabila nilai p-value statistic box's $M$ lebih besar dari 0.05. Dari hasil $p$-value statistik box's M diketahui bahwa nilai Box's $M$ sebesar 4.014 dengan signifikansi nilai $p$-value 0.714 , maka hipotesis $\mathrm{H}_{0}$ ditolak dan $\mathrm{H}_{\mathrm{a}}$ diterima, hal tersebut berarti varians antara data kelompok satu dan kelompok dua adalah data yang sifatnya homogeny.

\section{c) Uji Wilks' Lamda}

Wilk's Lambda diketahui nilai signifikansi statistics Chi-square sebesar $0,000(<0,05)$ yang berarti ada perbedaan yang signifikan antara kedua kelompok responden yang didasarkan pada ketiga variabel bebas 
Tabel 5. Wilks' Lamda

\begin{tabular}{|r|r|r|r|r|}
\hline \multicolumn{1}{|l|}{ Test of Function(s) } & Wilks' Lambda & Chi-square & df & Sig. \\
\hline 1 & 0.864 & 8.672 & 3 & 0.034 \\
\hline
\end{tabular}

Nilai Wilk's Lamda berkisar antara 0 hingga 1. Nilai Wilk's Lamda mendekati nol menunjukkan arti semakin signifikan karakteristik tersebut membedakan antara dua variasi kelompok. Sebaliknya, nilai Wilk's Lamda semakin mendekati angka 1, maka variasi data untuk karakteristik tersebut cenderung sama untuk dua kelompok tersebut. Berdasarkan pengujian Wilks' Lambda, maka diperoleh nilai Wilks' Lambda sebesar $0.864<1$ maka dapat dinyatakan bahwa variasi data untuk variabel kompensasi (X1), pengembangan karir (X2) dan lingkungan kerja (X3) cenderung berbeda antara pegawai yang tidak puas dalam bekerja dengan pegawai yang merasa puas dalam bekerja. Hal serupa juga dapat dilihat pada nilai signifikansi hasil uji Wilk's Lamda.

\section{d) Uji Struktur Matrix}

Uji ini digunakan untuk mengetahui apakah matriks struktur menunjukkan bahwa adanya korelasi antar variabel-variabel berikut ini:

Tabel 6. Structure Matrix

\begin{tabular}{|c|cr|}
\hline & \multicolumn{2}{|c|}{ Function } \\
\cline { 2 - 3 } & 1 & 0.940 \\
\hline Pengembangan karir & & 0.375 \\
Kompensasi & & 0.086 \\
\hline
\end{tabular}

Pooled within-groups correlations between discriminating variables and standardized canonical discriminant functions

Variables ordered by absolute size of correlation within function.

Tabel struktur Matrix menunjukkan urutan karasteristik yang paling membedakan kepuasan kerja pegawai $(\mathrm{Y})$. Variabel pengembangan karir $\left(\mathrm{X}_{2}\right)$ adalah yang paling membedakan karena memiliki nilai tertinggi sebesar 0.940 dibandingkan dengan nilai dimensi kompensasi $\left(\mathrm{X}_{1}\right)$ 0.375, dan nilai dimensi lingkungan kerja $\left(\mathrm{X}_{3}\right)$ sebesar 0.086 . Tabel di atas menunjukkan adanya korelasi antar variabel-variabel bebas dengan fungsi diskriminan yang terbentuk.

\section{e) Uji Cannonical Diskriminant dan Group Centreoids}

Tabel 7. Cannonical diskriminant function coefficients

\begin{tabular}{|l|rr|}
\hline & \multicolumn{2}{|c|}{ Function } \\
\cline { 2 - 3 } & \multicolumn{1}{|c|}{1} & 0.786 \\
\hline Kompensasi & & 2.785 \\
Pengembangan karir & & 0 \\
Lingkungan kerja & & -13.992 \\
(Constant) & & \\
\hline
\end{tabular}

Unstandardized coefficients

Author : Nurhidayat et al. (Oktober, 2017). 78 - 89 
Issue 2 (Oktober, 2017)

\section{f) Uji Functions at group centroids}

Tabel 8. Functions at group centroids

\begin{tabular}{|l|rr|}
\hline \multirow{2}{*}{ Kepuasan kerja } & \multicolumn{2}{|c|}{ Function } \\
\cline { 2 - 3 } & \multicolumn{2}{|c|}{1} \\
\hline tidak puas & & -0.247 \\
puas & & 0.616 \\
\hline
\end{tabular}

Unstandardized canonical discriminant functions evaluated at group means

Tabel Canonical Discriminat Function Coefficients di atas menunjukkan fungsi diskriminan dengan persamaan sebagai berikut :

$$
\text { Z-score }=-13.992(\text { konstan })+0.786\left(\mathrm{X}_{1}\right)+2.785\left(\mathrm{X}_{2}\right)+0.000\left(\mathrm{X}_{3}\right)
$$

Fungsi ini berguna untuk menganalisis kasus atau responden yang diteliti akan termasuk ke dalam kepuasan kerja pegawai, terdapat dua grup yang berbeda yaitu pegawai yang tidak puas dalam bekerja dengan centroid (rata-rata pegawai) negatif dan pegawai yang merasa puas dalam bekerja dengan centroid (rata-rata pegawai) positif.

\section{g) Uji Hasil Klasifikasi}

Klasifikasi penelitian tersebut dapat dilakukan berdasarkan beberapa tinjauan berdasarkan kepuasan kerja pegawai.

Tabel 9. Calssification result

\begin{tabular}{|c|c|c|c|c|c|}
\hline \multirow[b]{2}{*}{ Kepuasan kerja } & & & \multicolumn{2}{|c|}{$\begin{array}{l}\text { Predicted Group } \\
\text { Membership }\end{array}$} & \multirow[b]{2}{*}{ Total } \\
\hline & & & $\begin{array}{l}\text { tidak } \\
\text { puas }\end{array}$ & puas & \\
\hline \multirow[t]{4}{*}{ Original } & Count & tidak puas & 35 & 10 & 45 \\
\hline & & puas & 7 & 11 & 18 \\
\hline & $\%$ & tidak puas & 77.8 & 22.2 & 100 \\
\hline & & puas & 38.9 & 61.1 & 100 \\
\hline
\end{tabular}

a. $73.0 \%$ of original grouped cases correctly classified.

Tabel di atas pada kolom Original baris pada pegawai yang tidak puas sebanyak 35 responden atau sebesar $77.8 \%$, sedangkan baris pada pegawai yang merasa puas dalam bekerja sebanyak 7 responden atau sebesar 38.9\%. Dengan demikian dapat diketahui bahwa jumlah keseluruhan responden sebesar 63 responden dan terdistribusi secara normal.

\section{h) Uji Rata-Rata Tingkat Kesesuaian Group}

Tabel 10. Test of Equality of Group Means

\begin{tabular}{|l|r|r|r|r|r|}
\hline & Wilks' Lambda & F & df1 & df2 & \multicolumn{1}{c|}{ Sig. } \\
\hline Kmpnsasi & 0.978 & 1.348 & 1 & 61 & 0.25 \\
PKarier & 0.878 & 8.463 & 1 & 61 & 0.005 \\
LKerja & 0.999 & 0.07 & 1 & 61 & 0.792 \\
\hline
\end{tabular}




\section{JURNAL ORGANISASI DAN MANAJEMEN}

Issue 2 (Oktober, 2017)

Nilai rata-rata kesesuaian antar grup berdasarkan tingkat signifikansinya menunjukkan bahwa kebebasan:

1) Variabel kompensasi dengan nilai signifikansi (P-value) sebesar $0.250>0.05$ hal tersebut menjelaskan bahwa tingkat kompensasi pada badan kesatuan bangsa dan politik tidak adanya pengaruh terhadap kepuasan kerja pegawai sehingga hasilnya lebih besar dari nilai signifikansinya..

2) Variabel pengembangan karir dengan nilai signifikansi (P-value) sebesar $0.005<0.05$ hal tersebut menjelaskan bahwa semakin tinggi tingkat pengembangan karir pada kesatuan bangsa dan politik maka semakin tinggi tingkat kualitas kehidupan kerjanya sehingga hasilnya lebih kecil dari nilai signifikansinya..

3) Variabel lingkungan kerja dengan nilai signifikansi (P-value) sebesar $0.792>$ 0.05 hal tersebut menjelaskan bahwa lingkungan kerja pada badan kesatuan bangsa dan politik tidak adanya pengaruh terhadap kepuasan kerja pegawai sehingga hasilnya lebih besar dari nilai signifikansinya.

Pembuktian penerimaan hipotesa dalam penelitian ini menggunakan uji fisher (uji-f), yang dapat diuraikan sebagai berikut:

(1) Jika f-hitung < f-tabel, maka HO diterima dan H $\alpha$ ditolak, bahwa terdapat pengaruh yang tidak signifikan antara variabel kompensasi, peengembangan karir dan lingkungan kerja terhadap kepuasan kerja pegawai.

(2) Jika f-hitung > f-tabel, maka HO ditolak dan H $\alpha$ diterima, bahwa terdapat pengaruh yang signifikan antara variable kompensasi pengembangan karir dan lingkungan kerja terhadap kepuasan kerja pegawai.

Hasil penelusuran nilai $f$-tabel dapat ditelusuri dengan menggunakan bantuan microsoft excel, untuk itu dapat ditunjukkan pada gambar berikut:

Gambar 1. Hasil Uji f-tabel

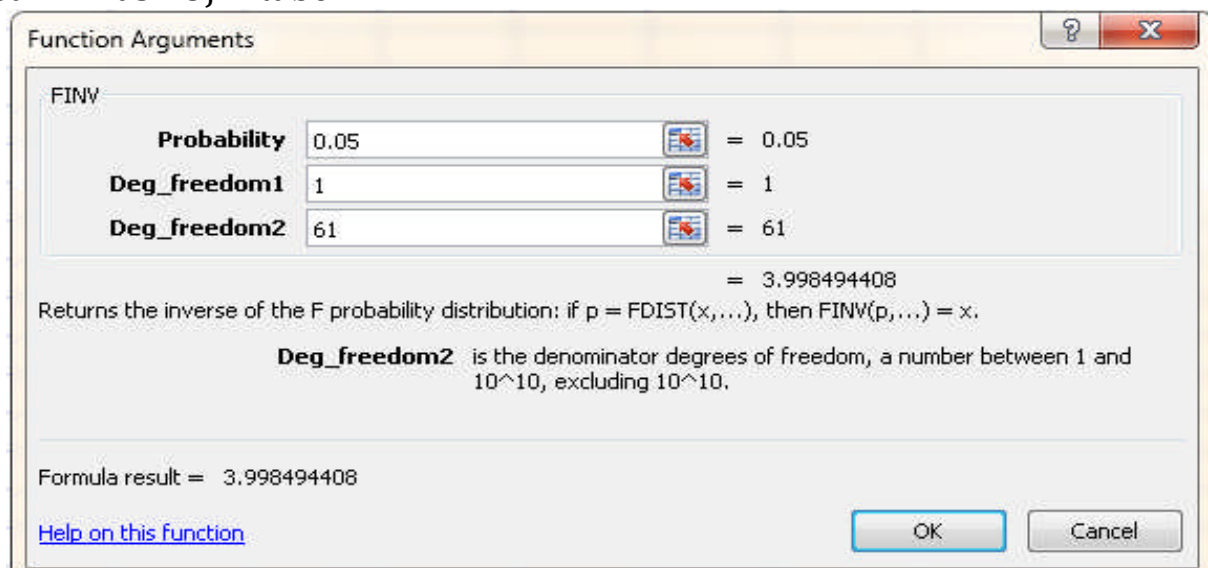

Gambar tersebut menunjukkan bahwa nilai degree of freedom untuk df $1=1$ dan pada df $2=61$ sehingga berdasarkan hasil tersebut dapat ditentukan nilai $f$ tabel sebesar 3.998. Merujuk pada hasil uji rata-rata hasil kesesuain grup dan nilai ftabel maka dapat dijelaskan faktor-faktor yang signifikan membedakan antara dua grup yaitu grup yang merasa tidak puas dalam bekerja dan grup yang merasa puas dalam bekerja.

Author : Nurhidayat et al. (Oktober, 2017). 78 - 89

Halaman 87 https://dx.doi.org/10.17605/OSF.IO/KY6NQ 


\section{JURNAL ORGANISASI DAN MANAJEMEN}

Issue 2 (Oktober, 2017)

Untuk uji-f digunakan sebagai uji hipotesis dan nilai p-value (signifikan) di mana jka p-value $>0,05$, berarti tidak ada perbedaan antara group dan jika p-value < 0,05 , artinya terdapat perbedaan antara group. Berdasarkan pengujian yang telah dilakukan, maka:

(1) Variabel kompensasi mempunyai nilai f-hitung pada variabel kompensasi sebesar $1.348<f$-tabel sebesar 3.998. Kemudian nilai $p$-value sebesar 0.250 $>0.05$, hal ini berarti bahwa group yang merasa tidak puas (pegawai yang merasa tidak puas) memiliki persepsi yang tidak terdapat perbedaan dengan group yang merasa puas (pegawai yang merasa puas) terhadap kepuasan kerja pegawai.

(2) Variabel pengembangan karir mempunyai nilai f-hitung pada variabel pengembangan karir sebesar $8.463>f$-tabel sebesar 3.998. Kemudian nilai $p$-value sebesar $0.005<0.05$, hal ini berarti bahwa group yang merasa tidak puas (pegawai yang merasa tidak puas) memiliki persepsi yang terdapat perbedaan dengan group yang merasa puas (pegawai yang merasa puas) terhadap kepuasan kerja pegawai.

(3) Variabel lingkungan kerja mempunyai nilai f-hitung pada variabel lingkungan kerja sebesar $0.070<f$-tabel sebesar 3.998. Kemudian nilai $p$ value sebesar $0.792>0,05$, hal ini berarti bahwa group yang merasa tidak puas (pegawai yang merasa tidak puas) memiliki persepsi yang tidak terdapat perbedaan dengan group yang merasa puas (pegawai yang merasa puas) terhadap kepuasan kerja pegawai.

\section{Kesimpulan}

Kompensasi $\left(\mathrm{X}_{1}\right)$ berpengaruh positif dan tidak signifikan sehingga dari pengujian tersebut dapat dikatakan bawah pegawai merasa tidak puas dengan kualitas kehidupan kerja terhadap kepuasan kerja pegawai pada Kesatuan Bangsa dan Politik Kota Makassar. Pengembangan Karir $\left(\mathrm{X}_{2}\right)$ berpengaruh positif dan signifikan sehingga dari pengujian tersebut dapat dikatakan bawah pegawai merasa puas dengan kualitas kehidupan kerja terhadap kepuasan kerja pegawai pada Kesatuan Bangsa dan Politik Kota Makassar. Lingkungan Kerja $\left(\mathrm{X}_{3}\right)$ berpengaruh positif dan tidak signifikan sehingga dari pengujian tersebut dapat dikatakan bawah pegawai merasa tidak puas dengan kualitas kehidupan kerja terhadap kepuasan kerja pegawai pada Kesatuan Bangsa dan Politik Kota Makassar. Faktor dominan yang mempengaruhi kualitas kehidupan kerja terhadap kepuasan kerja pegawai pada Kesatuan Bangsa dan Politik Kota Makassar yang paling dominan yaitu pengembangan karir.

Dimensi dari faktor-faktor kualitas kehidupan kerja yaitu kompensasi, pengembangan karir dan lingkungan kerja terhadap kepuasan kerja pegawai diharapkan dapat memperhatikan dimensi tersebut guna meningkatkan kepuasan kerja pegawai dimasa yang akan datang dan instansi harus lebih memperhatikan kualitas kehidupan kerja pegawai dalam mencapai rasa puas pegawai dalam bekerja.

\section{DAFTAR PUSTAKA}

Azis, A., \& Basuki, I. (2017). Analisis diskriminan pada tingkat kinerja pegawai yang di pengaruhi faktor-faktor budaya kerja (Studi Pada Dinas Kebersihan dan 


\section{JURNAL ORGANISASI DAN MANAJEMEN}

Issue 2 (Oktober, 2017)

Pertamanan Kota Madiun). Epicheirisi: Jurnal Manajemen, Administrasi, Pemasaran dan Kesekretariatan, 1(1), 1-7.

Dermawan, R. (2012). Analisis dan Perancangan Sistem Informasi Akuntansi Persediaan Pada CV Pakis Karunia Dalam Rangka Meningkatkan Pengendalian Internal (Studi Kasus: Perusahaan Produksi Kantong Kertas). Skripsi S-1 Tidak Dipublikasikan.

Istianto, M. (2007). Perkembangan dan Kemampuan Reproduksi Tungau Panonychus citri McGregor (Acarina: Tetranychidae) yang Resisten dan Peka terhadap Akarisida. Jurnal Hortikultura, 17(2).

Keith, Davis \& Newstrom, Jhon W. (2000). Perilaku Dalam Manajemen Sumber Daya Manusia, Edisi ke-7. Jakarta.

Nitisemito, Alex S. (2000). Manajemen Personalia: Manajemen Sumber. Daya Manusia, Ed. 3. Ghalia Indonesia, jakarta. Almigo, Nuzsep. 2004.

Paramita, A., \& Kristiana, L. (2013). Teknik Focus Group Discussion Dalam Penelitian Kualitatif. Buletin Penelitian Sistem Kesehatan, 16(2 Apr).

Rivai, Veithzal. (2010). Audit Kinerja Pada Sektor Publik: Konsep, Praktik,Studi Kasus. Jakarta: Salemba Empat.

Robbins, Stephen P. (1996). Perilaku Organisasi, konsep, Kontroversi, dan. Aplikasi. Alih Bahasa :HAdyana Pujaatmaka. Edisi : Keenam. Jakarta : Penerbit PT.

Simamora, Henry. (2006). Akuntansi Basis Pengambilan Keputusan Bisnis,. Jakarta : Salemba Empat.

Sulistiyorini, I. (2013). analisis faktor-faktor yang mempengaruhi kepuasan pelanggan internet speedy reguler menggunakan analisis diskriminan di semarang (Doctoral dissertation, Universitas Negeri Semarang) 